\title{
Analysis of Calcium (Ca) and Potassium (K) Levels in Mackerel (Rastrelliger sp.) Bones
}

\author{
*Ni Luh Ayu Murtini \& Baharuddin Hamzah \\ Pendidikan Kimia/FKIP - Universitas Tadulako, Palu - Indonesia 94119 \\ Received 05 June 2020, Revised 03 July 2020, Accepted 04 August 2020 \\ doi: 10.22487/j24775185.2020.v9.i3.pp143-147
}

\begin{abstract}
Mackerel (Rastrelliger sp.) is one of the potential pelagic fish in Indonesia and in almost all Indonesian waters. In general, fish bones contain many essential ingredients for the body and can be processed into fish bone flour. This study aimed to determine calcium (Ca) and potassium (K) levels in mackerel (Rastrelliger sp.) bones. Calcium and potassium levels were determined using an atomic absorption spectrophotometry (AAS). Results of the analysis showed that the water, ash, and biomass levels of the sample were 10.53, 18.26, and 71.21\%, respectively. Analysis of calcium and potassium levels at wavelengths 422.7 $\mathrm{nm}$ and $766.5 \mathrm{~nm}$ obtained an average of 508.15 and $36.37 \mathrm{mg} / 100 \mathrm{~g}$. The results indicate that the calcium level is higher than the potassium level in mackerel (Rastrelliger sp.) bones.
\end{abstract}

Keywords: Mackerel bones, calcium, potassium, atomic absorption spectrophotometry (AAS)

\section{Pendahuluan}

Ikan merupakan salah satu bahan makanan yang dibutuhkan manusia. Selain itu apabila dibandingkan dengan sumber penghasil protein lain seperti daging, dan susu, harga ikan relatif lebih murah (Lawang, 2013). Salah satu sumber daya alam yang potensial adalah ikan kembung. Berdasarkan data oleh Kementerian Kelautan dan Perikanan (Rahmantya dkk., 2012) hasil tangkap ikan kembung di Jawa Tengah merupakan salah satu komoditi tangkapan terbesar yaitu sebesar 11704 ton. Ikan kembung dikenal sebagai mackarel fish yang termasuk ikan ekonomis penting dan potensi tangkapannya naik tiap tahunnya.

Ikan kembung termasuk ikan pelagis dan merupakan salah satu ikan tangkap yang tersebar diseluruh perairan Indonesia. Bagian yang dapat dimakan dari ikan kembung sebesar $80 \%$ dan 20\% merupakan limbah perikanan (Hartari \& Anang, 2013). Pada pengolahan produk atau makanan yang berasal dari ikan kembung seperti industri rumah tangga pembuatan siomai dan abon ikan yang dimanfaatkan hanya dagingnya saja sehingga pada produksi tersebut tulangnya dibuang.

Tulang ikan termasuk limbah padat. Limbah padat lebih dikenal sebagai sampah yang sering kali tidak dikehendaki kehadirannya karena tidak memiliki nilai ekonomis. Kehadiran limbah sangat berdampak negatif terhadap lingkungan terutama bagi manusia sehingga perlu dilakukan penanganan terhadap limbah (Astrina dkk., 2010). Salah satu bentuk pemanfaatan tulang ikan yaitu dengan mengolahnya menjadi tepung tulang ikan.
Pemafaatan tulang ikan menjadi tepung tulang ikan merupakan salah satu upaya yang dapat mengurangi jumlah limbah perikanan dan secara tidak langsung menyumbang asupan kalsium untuk masyarakat Indonesia.

Tepung tulang ikan dapat ditambahkan pada produk ektruksi, roti, biscuit dan kue kering. Selain itu, juga sebagai bahan baku tambahan dalam pembuatan pakan ternak, baik pakan ternak ruminansia, ternak unggas maupun pelet ikan. Tepung ikan yang berasal dari kepala dan tulang offal mengandung lebih banyak mineral sedangkan tepung ikan tersebut berasal dari isi perut atau ikan utuh, kandungan mineral lebih kecil (Maulida, 2005).

Penelitian yang telah dilakukan mengenai pemanfaatan limbah tulang ikan meliputi pemanfaatan limbah tulang ikan tuna (Thunnus sp.) sebagai sumber kalsium (Trilaksani dkk., 2006), fortifikasi tepung tulang Tuna sebagai sumber kalsium (Wardani dkk., 2012), karakterisasi biskuit dengan penambahan tepung tulang ikan Jangalius (Istiophorus sp.) (Pratama dkk., 2014), fortifikasi tepung tulang ikan Gabus (Channa striata) pada kerupuk sebagai sumber kalsium (Putra dkk., 2015).

Mineral terdapat di dalam tubuh dan memegang peranan penting dalam pemeliharaan fungsi tubuh, baik tingkat sel, jaringan, organ maupun fungsi tubuh secara keseluruhan. Keseimbangan mineral di dalam tubuh diperlukan untuk pengaturan kerja enzim, pemeliharaan keseimbangan asam basa, dan kepekaan saraf terhadap rangsangan. Kalsium berperan dalam pembentukan tulang dan gigi (Almatsier, 2002).

*Correspondence:

Ni Luh Ayu Murtini

e-mail: ayuniluh676@gmail.com

(c) 2020 the Author(s) retain the copyright of this article. This article is published under the terms of the Creative Commons Attribution License 4.0, which permits unrestricted non-commercial use, distribution, and reproduction in any medium, provided the original work is properly cited. 
Kalsium merupakan salah satu nutrien esensial yang dibutuhkan untuk berbagai fungsi tubuh (Gobinathan dkk., 2009).

Kalsium merupakan mineral yang paling banyak terdapat di dalam tubuh, diperkirakan 99\% kalsium terdapat di dalam jaringan keras yaitu tulang dan gigi dan $1 \%$ kalsium terdapat pada darah dan jaringan lunak. Tanpa 1\% kalsium, otot akan mengalami gangguan kontraksi, darah akan sulit membeku, rangsangan saraf akan terganggu dalam penghantarannya. Untuk memenuhi kebutuhan 1\% kalsium, tubuh mendapatkannya dari makanan yang dimakan atau dari tulang, karena mayoritas mineral dan vitamin tidak dapat diproduksi sendiri oleh tubuh (Lestari \& Dwiyana, 2016).

Kalium adalah mineral penting yang diperlukan tubuh dalam pengaturan keseimbangan cairan tubuh, untuk kontraksi otot, dan menjaga kesehatan sistem saraf. Sebanyak 95\% kalium berada di dalam cairan intraseluler. Bahan pangan yang mengandung kalium baik dikonsumsi penderita tekanan darah tinggi. Kebutuhan kalium diperkirakan sebesar $2000 \mathrm{mg} /$ hari (Rahmelia dkk., 2015).

Kalium juga merupakan mineral yang bermanfaat untuk mengendalikan tekanan darah, terapi darah tinggi, serta membersihkan karbondioksida di dalam darah. Kekurangan kalium dapat memberi efek buruk dalam tubuh karena mengakibatkan hipokalemia yang menyebabkan frekuensi denyut jantung melambat. Sedangkan untuk kelebihan kalium mengakibatkan hiperkalemia yang menyebabkan aritmia jantung, konsentrasi yang lebih tinggi lagi yang dapat menimbulkan henti jantung atau fibrilasi jantung (Yaswir \& Ferawati, 2012).

Tulisan ini dimaksudkan untuk mendeskripsikan kadar kalsium (Ca) dan kalium (K) didalam tulang ikan kembung sehingga dapat dimanfaatkan sebagai tepung tulang ikan.

\section{Metode}

Alat yang digunakan dalam penelitian ini adalah Spektrofotometri Serapan Atom (SSA) (GBC 923 AA), lampu katoda untuk kalsium dan kalium, neraca digital, oven (MMM Medcenter), labu ukur, pipet volum, karet penghisap, gelas ukur, gelas kimia, cawan penguap, batang pengaduk, spatula, corong, tanur (FB1410M), desikator, botol semprot, pipet tetes.

Bahan yang digunakan dalam penelitian ini adalah tulang ikan kembung (Rastrelliger sp.), $\mathrm{HNO}_{3}$ 65\% (Merck), larutan standar kalsium (Merck), larutan standar kalium (Merck), aquades, tisu dan kertas saring.

\section{Pengambilan Sampel}

Sampel yang digunakan pada penelitian ini adalah tulang ikan kembung (Rastrelliger sp.) yang sudah dipisahkan dari dagingnnya. Ikan kembung segar di peroleh dari Pasar Tambarana Kecamatan Poso Pesisir Utara.
Memilih ikan kembung segar kemudian membersihkan bagian dalamnya yang meliputi jeroan dan insangnya. Selanjutnya memisahkan tulang badan dengan dagingnya dan untuk tulang kepalanya di bersihkan dari daging, kulit, otak dan mata lalu mencuci tulang ikan kembung dengan air hingga bersih, selanjutnya dikeringkan (dianginanginkan pada suhu ruangan).

\section{Penentuan Kadar Air dan Kadar Abu}

Sampel tulang yang sudah kering, kemudian dimasukkan ke dalam cawan penguap dan ditimbang sebanyak 50 gram, lalu dipanaskan dalam oven pada suhu $105^{\circ} \mathrm{C}$ selama \pm 3 jam. Setelah itu didinginkan dalam desikator dan ditimbang. Kemudian ditentukan kadar airnya dengan rumus kadar air (Sudarmadji dkk., 2010).

Sampel tulang 1 dan 2 yaitu 44.77 gram dan 44.70 kering yang telah diperoleh kemudian diabukan dalam tanur pada suhu $700^{\circ} \mathrm{C}$ selama \pm 3 jam. Kemudian abu yang diperoleh ditimbang dan ditentukan kadar abunya dengan rumus kadar abu (Sudarmadji dkk., 2010).

\section{Preparasi Sampel}

Sampel abu sampel tulang 1 dan 2 dipisah masingmasing sebesar 2,5gram dan ditambahkan larutan $\mathrm{HNO}_{3}$ pekat sebanyak $5 \mathrm{~mL}$ ke dalam masingmasing sampel, kemudian disaring, hingga terpisah antara filtrat dan residu. Filtrat yang diperoleh selanjutnya diencerkan dengan aquades dalam labu ukur $50 \mathrm{~mL}$ sampai tanda batas.

\section{Analisis Kadar Kalsium dan Kalium}

Larutan sampel tulang ikan kembung yang telah diperoleh diambil beberapa $\mathrm{mL}$ kemudian analisis kalsium dan kalium menggunakan alat spektrofotometer serapan atom pada panjang gelombang yang digunakan yaitu $422.7 \mathrm{~nm}$ dan $766.5 \mathrm{~nm}$.

\section{Hasil dan Pembahasan}

\section{Kadar Air dan Kadar Abu pada Tulang Ikan Kembung}

Analisis kadar air bertujuan untuk mengetahui seberapa besar kadar air dalam tulang ikan kembung yang akan dianalisis. Kadar air merupakan salah satu parameter yang paling menentukan karakter dan umur simpan suatu bahan pangan. Secara umum, semakin tinggi kadar air suatu bahan pangan, maka semakin singkat umur bahan pangan tersebut (Winarno, 2004). Ada beberapa metode analisis kadar air pada sampel, diantaranya adalah metode pengeringan/oven, metode destilasi dan metode kimiawi. Pada Penelitian ini, analisis kadar air menggunakan metode pengeringan dengan oven.

Metode pengeringan dengan oven didasarkan atas prinsip perhitungan selisih bobot bahan sampel sebelum dan sesudah pengeringan. Selisih bobot tersebut merupakan air yang menguap dan dihitung sebagai kadar air bahan. Prinsip dari metode pengeringan adalah bahwa air yang terkandung dalam suatu bahan akan menguap bila 
bahan tersebut dipanaskan pada suhu $105^{\circ} \mathrm{C}$ selama waktu tertentu (Legowo dkk., 2007).

Hasil penelitian ini menunjukkan bahwa tulang ikan kembung mempunyai kadar air sebesar $10.53 \%$. Kadar air tulang ikan kembung lebih rendah jika dibandingkan dengan kadar air tulang ikan bandeng yaitu untuk ikan bandeng umur 2 bulan kadar air tulang badan sebesar 18.31\%, untuk tulang kepala kadar air sebesar $11.31 \%$, dan umur 5 bulan kadar air tulang badan sebesar $14.94 \%$, untuk tulang kepala kadar air sebesar 11.31\% (Dewi, 2018). Berdasarkan kadar air yang diperoleh dapat dikatakan bahwa tulang ikan kembung memiliki daya tahan simpan bahan pangan lebih lama dibandingkan dengan tulang ikan bandeng.

Menentukan suatu mineral dalam suatu bahan pangan, terlebih dahulu dilakukan proses destruksi atau pengabuan. Ada dua prosedur yang umum digunakan untuk mendestruksi bahan-bahan organik dalam sampel yaitu dengan oksidasi basah (wet oxidation) dan pengabuan kering (dry ashing) (Tehubijuluw dkk., 2013). Pada penelitian ini dekstruksi sampel menggunakan pengabuan kering. Proses destruksi atau pengabuan berfungsi untuk memutuskan ikatan antara senyawa organik dengan logam yang akan dianalisis.

Proses pengabuan menggunakan tanur pada suhu $700^{\circ} \mathrm{C}$ selama \pm 3 jam, ini karena titik didih kalsium yaitu $1484{ }^{\circ} \mathrm{C}$ dan titik didih kalium yaitu $758.8{ }^{\circ} \mathrm{C}$. Pengabuan ini dilakukan sampai sampel menjadi abu yang berwarna keabu-abuan yang menandakan bahwa pengabuan sempurna. Hal ini berfungsi untuk mengoksidasi semua zat organik pada suhu tinggi dan untuk mempercepat dan menyempurnakan proses destruksi. Penggunaan tanur juga dapat mengatur suhu yang diinginkan.

Kadar abu yang diperoleh merupakan bahan-bahan anorganik yang tidak terbakar dalam proses pengabuan, sedangkan bahan-bahan organik terbakar. Kadar abu dalam suatu bahan pangan sangat mempengaruhi sifat bahan pangan tersebut. Kandungan abu dan komposisinya bergantung pada macam bahan dan cara pengabuan yang digunakan (Winarno, 2004).

Hasil kadar abu yang diperoleh dari sampel tulang ikan kembung sebesar 18.26\%. Kadar abu tulang ikan kembung lebih besar jika dibandingkan dengan kadar abu tulang ikan bandeng yaitu umur 2 bulan kadar abu tulang badan sebesar $15.19 \%$, tulang kepala sebesar $14.38 \%$, dan umur 5 bulan kadar tulang badan sebesar $16.51 \%$, tulang kepala sebesar 13.18\% (Dewi, 2018). Berdasarkan kadar abu yang diperoleh menunjukan bahwa tulang ikan kembung memiliki kadar mineral yang lebih tinggi dibandingkan dengan tulang ikan bandeng.

\section{Analisis Kadar Kalsium (Ca) dan Kalium (K) dalam Sampel Tulang Ikan Kembung}

Penentuan kadar kalsium dan kalium pada sampel tulang ikan kembung bertujuan untuk mengetahui kadar kalsium dan kalium dalam tulang ikan kembung (Rastrelliger sp.) dengan menggunakan metode Spektrofotometri Serapan Atom (SSA).
Dengan menggunakan alat spektrofotometer serapan atom, maka sampel yang akan diukur harus berupa larutan. Oleh karena itu sampel diabukan selama 3 jam untuk menguraikan senyawa-senyawa organik lain yang terdapat dalam sampel serta untuk memudahkan penentuan kadar kalsium dan kalium dalam sampel. Sampel abu yang diperoleh dari proses pengabuan kemudian dilarutkan dengan menambahkan larutan $\mathrm{HNO}_{3}$ pekat sebanyak $5 \mathrm{~mL}$. $\mathrm{HNO}_{3}$ pekat berfungsi untuk melarutkan logamlogam yang terdapat di dalam sampel, karena $\mathrm{HNO}_{3}$ pekat merupakan pelarut logam yang universal dan dapat menstabilkan logam-logam yang akan dianalisis (Hidayati, 2011). Analisis konsentrasi kadar kalsium dalam sampel tulang ikan Kembung dengan menggunakan SSA disajikan dalam Tabel 1:

Tabel 1. Data kosentrasi dan kadar kalsium dan kalium dalam sampel tulang ikan Kembung

\begin{tabular}{cccc}
$\begin{array}{c}\text { Samp } \\
\text { el }\end{array}$ & Mineral & $\begin{array}{c}\text { Konsentrasi } \\
(\mathrm{mg} / \mathrm{L})\end{array}$ & $\begin{array}{c}\text { Kadar } \\
(\mathrm{mg} / 100 \mathrm{~g})\end{array}$ \\
\hline I & $\mathrm{Ca}$ & 8.07 & 494.30 \\
II & & 8.53 & 522.00 \\
\multicolumn{2}{c}{ Rata - rata } & 8.30 & 508.15 \\
I & K & 4.29 & 43.84 \\
II & & 2.84 & 28.90 \\
\multicolumn{2}{l}{ Rata - rata } & 3.57 & 36.37 \\
\hline
\end{tabular}

Hasil dari penelitian ini diperoleh rata-rata kadar kalsium sebesar $508.15 \mathrm{mg} / 100 \mathrm{~g}$ dan ratarata kadar kalium sebesar $36.37 \mathrm{mg} / 100 \mathrm{~g}$. Berdasarkan hasil penelitian dapat dikatakan bahwa tulang ikan kembung mempunyai kadar kalsium yang lebih tinggi dibandingkan dengan kadar kalium. Hal ini karena tulang ikan merupakan salah satu bentuk limbah padat dari industri pengolahan ikan yang memiliki kandungan kalsium terbanyak diantara bagian tubuh ikan, karena unsur utama dari tulang ikan adalah kalsium (Ca) dan fosfor (P) (Trilaksani dkk., 2006). Sedangkan kalium sebanyak 95\% berada di dalam cairan intraseluler yang berfungsi menjaga keseimbangan asam basa dan tekanan osmotik di dalam sel. Kalium plasma pada tulang sebesar $0.22 \% \mathrm{BK}$ dan $83.03 \mathrm{mg} / 100 \mathrm{~mL}$ (Sulastri, 2002).

Jika dilihat dari hasil yang diperoleh, tulang ikan kembung (Rastrelliger sp.) dapat diklaim sebagai bahan pangan tinggi kalsium dan tidak dapat diklaim sebagi bahan pangan sumber kalium. Menurut Badan Standarisasi Makanan, (2015) makanan dapat diklaim sebagai sumber mineral jika memenuhi syarat $15 \%$ dari ALG per 100 gram bahan dan dapat diklaim sebagai tinggi mineral jika memenuhi syarat dua kali dari jumlah sumber mineral. Berdasarkan ketentuan tersebut, yang dapat diklaim sebagai pangan sumber mineral (kalsium) adalah yang memiliki kadar minimal $120 \mathrm{mg}$ atau 0.12 gram dan yang dapat diklaim sebagai pangan tinggi mineral (kalsium) adalah yang memiliki kadar minimal 240 mg (Siswanti dkk., 2017).

Kadar kalsium yang dimiliki tulang ikan kembung relatif lebih tinggi jika dibandingkan 
dengan tulang ikan bandeng (Chanos chanos) dimana kadar kalsiumnya pada tulang badan dan kepala 2 bulan berturut-turut yaitu $0.052 \pm 0.0007 \%$ dan $0.132 \pm 0.0056 \%$. Sedangkan pada tulang badan dan kepala 5 bulan berturut-turut yaitu $0.197 \pm 0.0014 \%$ dan $0.138 \pm 0.0007 \%$ (Dewi, 2018).

Kalsium yang berasal dari hewan seperti tulang ikan sampai saat ini belum banyak dimanfaatkan untuk kebutuhan manusia. Tulang ikan banyak mengandung kalsium dalam bentuk kalsium posfat sebanyak $14 \%$ dari total susunan tulang. Bentuk kompleks posfat ini terdapat pada tulang. Unsur utama penyusun tulang ikan adalah kalsium, posfat dan karbohidrat, sedangkan yang terdapat dalam jumlah kecil yaitu magnesium, sodium, sitrat, stronsium, flourida, hidroksida dan sulfat (Tiwo dkk., 2016). Kalsium dan fosfor berhubungan erat dengan pengembangan kerangka dan pemeliharaan dan mineralisasi tulang (Rocha dkk., 2014). Dalam proses mineralisasi tulang, kalsium memiliki peran yang penting karena sekitar $80-90 \%$ unsur tulang tersusun dari $\mathrm{Ca}, \mathrm{P}$ dan $\mathrm{Mg}$ (Zainudin, 2010).

Fitriani dkk. (2012) mengatakan kalsium dan posforus membentuk kalsium fosfat atau kristal kalsium hidroksiapatit $\left[3 \mathrm{Ca}_{3}\left(\mathrm{PO}_{4}\right) 2 \mathrm{Ca}(\mathrm{OH})_{2}\right]$ sebagai penyusun utama pembentuk tulang. Penelitian lain yang dilakukan oleh Adebayo \& Omitoyin (2013) pada ikan, Ca kompleks dengan P dalam hidroksiapatit berfungsi untuk membentuk kepala, ekor, bahan kristal tulang dan berpartisipasi dalam beberapa proses fisiologi.

Pentingnya peranan kalsium bagi tubuh manusia sehingga dapat menjadikan tulang ikan kembung (Rastrelliger sp.) sebagai salah satu alternatif bahan yang dapat dimanfatkan sebagai tepung tulang ikan berkalsium tinggi. Menurut Trilaksani dkk. (2006) tepung tulang ikan tidak terlalu banyak digunakan dengan kata lain tepung tulang merupakan suatu pelengkap dalam pembuatan makanan.

\section{Kesimpulan}

Kadar air dalam tulang ikan kembung sebesar 10.53\%, kadar abu sebesar $18.26 \%$ dan kadar biomassa sebesar $71.21 \%$. Sedangkan ratarata kadar kalsium dalam tulang ikan kembung sebesar $508.15 \mathrm{mg} / 100 \mathrm{~g}$ dan rata-rata kadar kalium dalam tulang ikan kembung adalah $36.37 \mathrm{mg} / 100 \mathrm{~g}$. Hal ini menunjukkan bahwa di dalam tulang ikan kembung kadar kalsium lebih tinggi di bandingkan dengan kadar kalium.

\section{Ucapan Terima Kasih}

Ucapan terima kasih penulis berikan kepada laboran Laboratorium Kesehatan Daerah Provinsi Sulawesi Tengah dan semua pihakyang banyak membantu penulis dalam menyelesaikan penelitian ini.

\section{Referensi}

Adebayo, I. A., \& Omitoyin, B. O. (2013). Essentiality of calcium supplement in the diets of heterobranchus bidorsalis fingerlings. International Jurnal of Fisheries and Aquaculture, 5(5), 98-103.

Almatsier, S. (2002). Prinsip dasar ilmu gizi. Jakarta: PT. Gramedia Pustaka Utama.

Astrina, A., Ninda, \& Rahma. (2010). Pemanfaatan limbah tulang ikan bandeng (chanos chanos) sebagai bakso berkalsium tinggi. Diakses tanggal 23 Maret 2019, dari http:/ /kemahasiswaan.um.ac.id/wpcontent/uploads/2010/04/PKM-GT-2010UM-Aninda-Pemanfaatan-Tulang-IkanBandeng-.doc.

Badan Standarisasi Makanan. (2015). Makanan ringan ekstrudat. Jakarta: BSN.

Dewi, K. L. (2018). Analisis kadar kalsium (Ca) dalam tulang ikan bandeng (chanos chanos) menggunakan metode spektrofotometri serapan atom (SSA). Skripsi Tidak Diterbitkan. Palu: Universitas Tadulako.

Fitriani, N. L. C., Walanda, D. K., \& Rahman, N. (2012). Penentuan kadar kalium (K) dan kalsium (Ca) dalam labu siam (sechium edule) serta pengaruh tempat tumbuhnya. Jurnal Akademika Kimia, 1(4), 174-180.

Gobinathan, P., Sankar, B., Murali, P. V, \& Panneerselvam, R. (2009). Interactive effects of calcium chloride on salinity-induced oxidative stress in pennisetum typoidies. Botany Research International, 2(3), 143-148.

Hartari, A., \& Anang, S. (2013). Pengembangan cara pengemasan ikan kembung picungan untuk. meningkatkean daya simpan laporan kemajuan penelitian dosen pemula program studi ilmu dan teknologi pangan. Diakses tanggal 25 April 2019, dari https://adoc.pub/laporan-kemajuanpenelitian-dosen-pemula-pengembangan-carap.html.

Hidayati, S. N. (2011). Kadar kalsium (Ca) dan Kalium (K) pada sayur kangkung (ipomea reptans) yang tumbuh di kota Palu. Skripsi Tidak Diterbitkan. Palu: Universitas Tadulako.

Rahmantya, K. F., Asianto, A. G., Wibowo, D., Wahyuni, T., \& Somad, W. A. (2012). Analisis dan data pokoke kelautan dan perikanan menurutprovinsi tabun 2012. Jakarta: Pusat Data, Statistik dan Informasi.

Lawang, A. T. (2013). Pembuatan dispersi konsentrat ikan gabus (ophiocephalus striatus) sebagai makanan tambahan (food supplement). Skripsi Tidak Diterbitkan. Makassar: Universitas Hasanuddin.

Legowo, A. M. (2007. Academic curriculum development buku ajar analisis pangan. Semarang: Universitas Diponegoro.

Lestari, W. A., \& Dwiyana, P. (2016). Pemanfaatan limbah tulang ikan tuna (thunnus sp) dalam bentuk tepung pada pembuatan stick. Jurnal Ilmu Kesehatan, 8(2), 46-53.

Maulida N. (2005). Pemanfaatan tepung tulang ikan madidihang (thunnus albacares) sebagai suplemen dalampembuatan biskuit (crackers). Skripsi Tidak Diterbitkan. Bogor: Institut Pertanian Bogor. 
Pratama, R. I., Rostini, I., \& Liviawaty, E. (2014). Karakteristik biskuit dengan penambahan tepung tulang ikan jangilus (istiophorus sp.). Jurnal Akuatika, 5(1), 30-39.

Putra, M. R. A., Nopianti, R., \& Herpandi, H. (2015). Fortifikasi tepung tulang ikan gabus (channa striata) pada kerupuk sebagai sumber kalsium. FishtecH-Jurnal Teknologi Hasil Perikanan, 4(2), 128-139.

Rahmelia, D., Diah, A. W. M., \& Said, I. (2015). Analisis kadar kalium (K) dan kalsium (Ca) dalam kulit dan daging buah terung kopek ungu (solanum melongena) asal desa nupa bomba. Jurnal Akademika Kimia, 4(3), 143-148.

Rocha, C. B., Portelinha, M. K., Fernandes, J. M., Britto, A. C. P., Piedras, S. R. M., \& Pouey, L. O. F. (2014). Dietary phosphorus requirement of pejerrey fingerlings (odontesthes bonariensis). Revista Brasileira de Zootecnia, 43(2), 55-59.

Siswanti., Agnesia, P. Y., \& Katri, R. B., (2017). Pemanfaatan daging dan tulang ikan kembung (rastrelliger kanagurta) dalam pembuatan camilan stick. Jurnal Teknologi Hasil Pertanian, 10(1), 41-49.

Sudarmadji, S., Haryono, B., \& Suhardi. (2010). Analisa bahan makanan dan pertanian. Yogyakarta: Liberty.

Sulastri, A. (2002). Suplementasi rayap (glyptotermes montanus kemner) dalam ransum serta pengarubnya terbadap kandungan mineral ( $\mathrm{Na}$ dan K) plasma dan tulang ayam rokky-301. Skripsi Tidak Diterbitkan. Bogor: Institut Pertanian Bogor.
Tehubijuluw, H., Fransina, E. G., \& Pada, S. S. (2013). Penentuan kandungan logam Cd dan Cu dalam produk ikan kemasan kaleng secara spektrofotometri serapan atom (SSA). Jurnal Cakra Kimia, 1(1), 8-13.

Tiwow, V. M. A., Hafid, I. W., \& Supriadi. (2016). Analisis kadar kalsium (Ca) dan fosforus (P) pada limbah sisik dan sirip ikan mujair (oreochromis mossambicus) dari danau lindu sulawesi tengah. Jurnal Akademika Kimia, 5(4), 159-165.

Trilaksani, W., Salamah, E., \& Nabil, M. (2006). Pemanfaatan limbah tulang ikan tuna (thunnus sp.) sebagai sumber kalsium dengan metode hidrolisis protein. Jurnal Buletin Teknologi Hasil Perikanan, 9(2), 34-45.

Wardani, D. P., Liviawaty, E., \& Junianto. (2012). Fortifikasi tepung tulang tuna sebagai sumber kalsium terhadap tingkat kesukaan donat. Jurnal Perikanan dan Kelautan, 3(4), 41-50.

Winarno, F. G. (1992). Kimia pangan dan giz̨. Jakarta: PT Gramedia Pustaka Utama.

Yaswir, R., \& Ferawati, I. (2012). Fisiologi dan gangguan keseimbangan natrium, kalium dan klorida serta pemeriksaan laboratorium. Jurnal Kesebatan Andalas, 1(2), 80-85.

Zainudin. (2010). Pengaruh calsium dan fosfor terhadap pertumbuhan, efisiensi pakan, kandungan mineral dan komposisi tubuh juvenil ikan kerapu macan (epinephelus fuscoguttatus). Jurnal Ilmu dan Teknologi Kelautan Tropis, 2(2), 1-9. 